\title{
PRAGMATIC ANALYSIS ON BEST SELLING NOVEL A WALK TO REMEMBER BY NICHOLAS SPARKS
}

\author{
Moondi Emsita
}

INTISARI

\begin{abstract}
A Walk to Remember karya Nicholas Sparks adalah salah satu novel terlaris yang mampu menarik minat pembaca. Hal ini menimbulkan pertanyaan, elemen roman apa yang mampu menarik pembaca dalam memilih A Walk to Remember sebagai bacaan mereka. Pendekatan prakmatik digunakan untuk membantu menemukan formula roman berdasarkan pendapat pembaca dari sumber internet. Hasil dari kajian ini menunjukkan bahwa pembaca novel ini tertarik dengan cerita roman karena novel ini tidak hanya menceritakan kisah cinta namun juga beberapa pelajaran hidup. Selain itu novel ini mampu menarik minat pembaca karena cerita roman ini tidak berakhir dengan cerita bahagia. Novel ini dianggap lebih dari sekedar cerita roman, novel ini bisa disebut sebagai drama.
\end{abstract}

Kata Kunci: Penjualan terlaris, Drama, Cerita roman, Pendapat pembaca

\begin{abstract}
A Walk to Remember by Nicholas Sparks is one of The best-selling novels which is able to attract readers' attention. Accordingly, a question of what elements of romance attract readers in choosing A Walk to Remember as their reading arase. Pragmatic approach was used to help find the romance formula based on the readers' responses from internet sources. The result of the study showed that the readers of the novel were interested in the romance since it was not merely a love story, but it was also a story which presented moral values. In addition, this novel was able to attract readers since the romance story in the novel didn't end happily. This novel was considered as more than a romance, it could be considered a drama.
\end{abstract}

Keywords: Bestselling, Drama, Romance, Readers' responses

\section{INTRODUCTION}

Popular literature is a product of popular culture that is made to entertain readers. Jack Nachbar and Kevin Lause (1992:2) state, "Popular culture is not merely 'present', however it is also eager to please". Based on the theory, popular literature works in a society because people read them for enjoyment. People choose the product of popular literature because it is easy to be understood. It happens because the content of popular literature is not as difficult as serious fiction. Stanton (1965:8) supports this idea as he states, "The elements of popular fiction --- characters, situations, themes, devices---are usually stereotyped, and those in serious fiction are not". Further, according to Stanton (1965:2), "Serious fiction is more difficult to be understood because it contains two additional elements: a theme or central idea which the reader is expected to dig out to enjoy its full understanding".

In contrast to serious fiction, in enjoying the product of popular literature readers do not have to think deeply as Novelett Roberts states, "the best thing about popular literature is that you don't have to think about it". (http://www.shellythacker.com/marketsavvy. htm. (dod: November 15, 2011). Stanton (1965) also supports the idea by saying; most 
readers read the product of popular literature for enjoyment because popular literature is merely telling a story. Besides, the characteristic of popular literature is not merely about producing entertainment, it must be oriented in producing money. According to Bloom (2008), "Popular fiction is the expression of mass, industrial and consumer society". The previous explanation is supported by the evidence that today there is an increase in the number of publishers which publishe products of popular literature. These publisher produce many novels of popular literature genre. Ann Maxwell/Elizabeth Lowell states in her blog, "through the years, I've discovered that most publishers talk highly of literary fiction and make money on popular fiction" (http://www. elizabethlowell.com/popfiction.html. (dod: November 15, 2011).

Since the product of popular literature are easy to be understood and people like it, readers' interest in popular literature is getting bigger. Some people are interested in studying the products of popular literature. It can be seen that some students of English Department use products of popular literature in their graduating papers. Ummul Hasanah (2010) is one of the students who wrote about a product of popular literature in a graduating paper entitled "The Popular Formula of New York Times Best Seller Cathy's Book". Another study of popular literature was done by Desmaria Syahril (2007) in her graduating paper entitled "Formula and Archetype in Burroughs' Running with Scissors: A Study on Popular Genre". Both writers use different genre in analyzing the product of popular literature.

There are some genres in the popular literature. According to Cawelti (1976:39), "looking at the whole range of story formulas, there are five primary moral fantasies: Adventure, Romance, Mystery, Melodrama, Alien Beings or States". Among all the genres of literary study, romantic fictions are the most popular among the people of all agesyouths and seniors. In western countries romantic fictions are enlisted as the best sellers. In 2002 North America recorded 34.6\% sales of romantic fictions, whereas other fictions and mystery, detective and suspense stories contributed $24.2 \%$ and $23.1 \%$ sales respectively (http:www//.bestseller-romantic-fiction-books.html. (dod: November 15, 2011).

There are lots of romance novels. $A$ Walk to Remember is one of bestselling romance novels written by a best -selling author Nicholas Sparks. This novel is recommended to be read because this novel teaches that love has a power in changing someone's personality. Lots of people read $A$ Walk to Remember because it is cosidered a romance novel as states, "this novel was surely a beautiful love story, and also a stab in the heart if you really got into it" (http://www.goodreads.com/book/ show/3473.A_Walk_to_Remember">. (dod: November 15, 2011).

Accordingly, a question of what elements of romance attract readers in choosing A Walk to Remember as their reading arises. To find out the answer of the question, there are some objectives which will be able to help. The more specific objectives of the study are:

- To find out the formula of romance in the novel based on the readers' comment.

- To see how the formula of romance can attract people to read the novel.

- To see whether or not the romance in the novel is in accordance with the romance concept proposed by Radway (1984).

Since the study uses pragmatic approach, reader have an important role in the analysis. Based on the objective of the study, the analysis of the novel is only based on reviews from the readers from internet sources.

Since the novel is a new popular novel, there is no other research which analyzes this 
work. There is only an article on a website written by Terry Mattingly entitled "Clean, pro-faith film is a surprise hit". In the article, the writer emphasizes the faith or religion that the main character of the novel, Jamie, believes in (http://www.adherents.com/movies/ WalktoRemember.html. (dod: June 15, 2011). This study is more focusing in inquiring the formula of romance which succeed in attracting reader's attention to read the novel. It is definitely different from the previous article written by Terry.

\section{ROMANCE FORMULA IN $A$ WALK TO REMEMBER BASED ON READERS' RESPONSES}

In the analysis of the study, there are some elements that can be considered as romance formula since they are capable of attracting readers' attention. The elements are jamie's and London different personalities, the view of belief, romantic story, the ending and moral value such as knowing the inner quality of someone and love as a power to change someone's personality. Those elements are explained in the following analysis.

\section{- Moving Readers' Feeling}

Through Different Personality

The reader's interest in reading $A$ Walk to Remember is getting bigger. It can be seen that there are lots of reader's comments and reviews in this novel. The readers' comments and reviews show how readers can smile and cry because of the novel. This evidence proves that the novel is successful for moving the readers' emotion. The way the novel moves its readers is through many formulas such as dialogue, description of the atmosphere and the story itself. The character and characterization, however, are the main factors in attracting their attention. In analyzing this novel, the personality of a character has an important part rather than the physical appearance. It can be concluded that the novel has the capability of attracting the readers' attention by presenting the character's personalities. This idea is supported by Radway (1984:77),

...the relative excellence of a romance is a function of its treatment of three different aspects of the story. These include the personality of the heroine, the character of the hero, and the particular manner in which the hero pursues and wins the affections of the heroine.

From the theory, it obviously shows that the personalities of the character of the novel has an important part in inviting the reader's attention. This is seen in the fact that most readers only focus on the personalities of the major characters, Jamie and Landon. This idea is supported by morgancheer 1123 who states, "the different personalities of the two main characters, Jamie Sullivan and Landon Carter, will make you want to read on forever" (http:// www.barnesandnoble.com/w/walk-to-remember-nicholas-sparks/1100307860. (dod: January 16, 2012).

In the novel, Jamie is described as a nice girl who attracts readers with her pure heart. This is seen in a reader's comment named KRLA who gives the words, "While reading this book you will find yourself in love with these characters. Jamie, very innocent and pure" (http://www.amazon.com/AWalk-to Remember-ebook/product-reviews/ B000SEI230/ref $=\mathrm{cm} \_c r \_p r \_b t m \_l i n k \_31$ ? $\mathrm{i}$ e=UTF8\&showViewpoints $=0 \&$ pageNumb er=31.(dod: January 11, 2012). The condition is totally different from Landon who is depicted as a rebel and known as a bad boy. This is seen from stephanie_18 who contributes her words, "Landon is a sort of a bad boy" (http:// www.dealtime.com/A Walk to Remember by Nicholas Sparks/a-walk-to-remember/ RD-70684216964/reviews (dod: January 16, 2012). the following passage describes his personality:

So, I grew up under the care of my mother. Now she was a nice lady, sweet and gentle, 
the kind of mother most people dream about. But she wasn't, nor could she ever be, a manly influence in my life, and that fact, coupled with my growing disillusionment with my father, made me become something of a rebel, even at a young age (Spark, 8).

On the other hand, Jamie is also described as a contrast to Landon who always cares about other's opinion. A Kid's Review states, "I liked the book because Jamie is just an ordinary girl, who doesn't care about what others think of her" (http://www.amazon. com/A-Walk-to-Remember-ebook/productreviews/B000SEI230/ref $=\mathrm{cm}$ cr $\mathrm{pr}$ top lin $\mathrm{k}$ 76? ie $=$ UTF 8 \& show Viewpoints $=0$ \&page Number $=76$ (dod: January 11, 2012). It is totally different from Landon, his personality is obviously contrasted to Jamie's. Landon is depicted as a boy who is always aware of people's judgment about him. This statement is supported by a reader's comment named dramastef who states, 'Landon is your typical high school senior from the 50's. He is popular and does care about what his peers think of him, which causes him some problems during this story' (http://www.dealtime. com/A Walk to Remember by Nicholas Sparks/nicholas-sparks-ia-walk-to-rememberi-a-beautiful-book/RD-52407930500/reviews.(dod: January 16, 2012). The different personalities of Landon and Jamie attracts readers because they invite the reader's emotion into the novel. The reason why the novel invites readers to read the novel is because it presents the contrast personalities of the major character which is familiar in readers' life. In this case, it means that readers may adore the novel because they can get involved in the novel. As Iser (54) states in his article," This is why the reader often feels involved in events which, at the time of reading, seem real to him....". This is supported by ih8tweenies" who agrees with the statement, by saying, "telling the story of Landon and Jamie, two teenagers from very different backgrounds, $A$
Walk To Remember does that. It takes you on a journey of discovery and through an emotional rollercoaster" (http://www.amazon.com/ Walk-Remember-Nicholas-Sparks/productreviews $/ 0446693804 / \mathrm{ref}=\mathrm{cm}$ cr_pr top link $6 ?$ ie $=$ UTF $8 \&$ showViewpoints $=0$ \&pageNum ber $=6$. (dod: January 12, 2012).

From the readers' comments of the novel, it can be concluded that the different personality of good and bad personality between Jamie and Landon becomes an important aspect in the novel and it has capability in attracting readers' attention.

\section{- Through Jamie's View of Belief in God}

The different personalities of the major characters is not the only reason for readers to be attracted to the novel. There are lots of other reasons for instance, Jamie's view of belief. This becomes an important part in inviting readers to read the novel. Not only that Jamie is described as a nice girl, she is also depicted as a girl who really believes christianity. This creates an assumption that this novel is made for Christians. There is a comment from a reader who agrees with the statement. Miriam gives words on it, 'I think the book will probably be most meaningful to Christians' (http:// www.amazon.com/A-Walk-to-Remember-ebook/product-reviews/B000SEI230/ref $=\mathrm{cm}$ cr pr top link 14?ie=UTF8\&showViewpo ints $=0$ \&pageNumber $=14$. (dod: January 12, 2012). Jamie is a girl who always brings her bible wherever she goes. This habit of Jamie becomes the interesting part that attracts readers. One of the readers named Tylerpink "Tyler" states, "She was the religious girl who always had her bible" (http://www.amazon. com/A-Walk-to-Remember-ebook/productreviews/B000SEI230/ref $=\mathrm{cm}$ cr pr top lin $\mathrm{k} 17$ ? ie $=$ UTF8\&show Viewpoints $=0$ \&pageN umber $=17$. (dod: January 12, 2012). This is also supported by Angela M. Hooper "Angela M. Hooper" who gives opinion on it, "Where- 
as, Jamie - she keeps to herself, carries a bible, and dresses plainly. She is a great person with a 'big heart' (http://www.amazon.com/AWalk-to-Remember-ebook/product-reviews/ B000SEI230/ref $=\mathrm{cm}$ cr pr top link 14?i e=UTF 8\&show Viewpoints $=0$ \&pageNumb er=14. (dod: January 12, 2012). The characteristic of Jamie who believes in her religion invites readers to know more about the story. In the story Jamie is described as a good follower of God. Jamie always relates her life to Gods plan. The situation is clearly explained by the following description in the novel:

With Jamie, everything was in the Lord's plan. She always mentioned the Lord's plan whenever you talked to her, no matter what the subject. The baseball game's rained out? Must be the Lord's plan to prevent something worse from happening. A surprise trigonometry quiz that everyone in class fails? Must be in the Lord's plan to give us challenges (Spark, 14).

From the explanation, it can be seen that Jamie truly believes in God plan.

There are lots of statements that come from readers which also support the idea about Jamie's view of belief. Some of them give more attention on how she puts her life in God's plan. It totally arouses readers' emotion. This is clearly supported by Judith E. Pavluvcik who states, "her unnerving faith and trying to live her life as God wanted us all to live, endears her to the reader"(http://www. amazon.com/A-Walk-to-Remember-ebook/ product-reviews/B000SEI230/ref $=\mathrm{cm} \_\mathrm{cr} \_\mathrm{pr}$ top link 8?ie $=U T F 8 \&$ showViewpoints $=0 \& p$ ageNumber $=8$. (dod: January 12, 2012). The previous comment shows that Jamie attracts readers due to her faith in God. It is assumed that her capacity in attracting reader's attention is not only being a nice girl but also being a good Christian. This idea is supported by A. Luciano who also contributes his word on it, "she was so perfect and sweet and overbearingly religious" (http://www.amazon.
com/A-Walk-to-Remember-ebook/productreviews/B000SEI230/ref $=\mathrm{cm}$ cr pr top link 134? $\mathrm{ie}=\mathrm{UTF} 8$ \& show Viewpoints $=0$ \&pageN umber $=134$. (dod: January 12, 2012).

From some different readers' comments, it can be seen that they have similar opinion in adoring Jamie's faith. They admire Jamie as well because she has a great faith in God. Her faith is an interesting part in the novel to attract readers' attention. It can be concluded that readers need to read book which consist of several good things such as view of belief. From the presented comments, it can be concluded that through her belief, Jamie is successful in inviting the readers' emotion through the story which provides the Christian needs.

\section{- Inviting Reader's Emotion by Touch -} ing Story

- Romantic Story

This novel is successful in attracting readers' attention because it appeals to all readers who have ever experienced such a love story. The book itself is considered as a romance because it contains description of the love relationship between a man and a women. This idea is also supported by Radway (1984:65),

I think (a romance) is a man and woman meeting, the growing awareness, the culmination of the love---whether it's going to jell or if it's going to fall apart---but they [the heroine and the hero] have recognized that they have fallen in love [emphasis added].

The story of the novel is about the growing love relationship_between two young teenagers, Jamie and Landon. The story includes both happiness and sadness description of the relationship which succeeds in attracting the reader. This is seen from CaityyyCR's opinion; "A Walk to Remember was a very sweet book. It explains what the two most powerful things on earth are...Love, and Death..and 
how they can effect someones heart.I touched my heart" (http://www.barnesandnoble.com/ reviews/Walk-to-Remember\%2FNicholasSparks/1100307860?startat=141. (dod: January 16, 2012). This is supported by some readers who give similar opinion. It can be seen from df1a_rachelh who contributes an opinion on the subject, "I really enjoyed this book because it is a great love story" (http://www.librarything.com/work/8405130/reviews. (dod: November 17, 2011). Another reader named AllyLovesBooks gives the similar statement, "This book is one of my most favorites! It is so amazing! It will make you laugh and smile, and it is so romantic and cute" (http://www.barnesandnoble.com/w/walkto-remember-nicholas-sparks/1100307860. (dod:January16,2012). MaGicAllyGeNuisJ also supports the previous statement by saying, "I L.O.V.E this book, it was a great romance" (http://www.barnesandnoble.com/w/walkto-remember-nicholas-sparks/1100307860. (dod:January16,2012).

Since readers consider the book as a romance, it can be assumed that there are lots of romantic descriptions either from the dialogue or beautiful sceneries in the story which succeed in making readers' emotion raises. In the story, the author creates such beautiful words which are delivered by Landon to Jamie. This statement is supported by Alyson B Baxter_who states, "this is the most amazing book I have ever read. It took me only three hours to read the beautiful words of Nicholas Sparks from cover to cover. I laughed and then I sobbed...I would recommend this book to anyone willing to take a look at their own lives, and wonder what is missing..." (http:// www.amazon.com/Walk-Remember-Nicholas-Sparks/product-reviews/0446693804?pag eNumber=2. (dod: January 4, 2012).

One of the most favorite romantic dialogue which is adored by readers is when Landon confesses his love toward Jamie. It is supported by Lee Christina p 3 as she states,
"My favorite part of this book was when Landon told Jamie that he loved her" (http://www. amazon.com/A-Walk-to-Remember-ebook/ product-reviews/B000SEI230/ref $=\mathrm{cm}$ cr pr top link 83? ie $=$ UTF8\&showViewpoints $=0 \&$ pageNumber $=83$. (dod: January 12, 2012). In the story, the confession of love is described in the following description on the novel, "I love you, Jamie," I said to her. "You're the best thing that ever happened to me'. The confession of Landon's love toward Jamie attracts several readers' attention. The most romantic dialogue which attracts most of readers' emotion is when Landon asks Jamie to marry him. The description of the romantic dialogue is clearly described in the following passage,

Encouraged, I leaned closer and took a deep breath. When I exhaled, these were the words that flowed with my breath."Will you marry me?" (Spark, 137).

This part lets readers wish the developing love relationship between a man and a woman to grow further. Readers enjoy the romantic dialogue provided in the novel. This idea is supported by A Customer who states, "My favorite part of the book was when Landon asked Jamie if she wanted to marry him". The statement is supported by Lee Christina $p$ 3 who contributes her word by saying, "I also loved the part when Landon thinks of marrying Jamie, asked her, and she said yes..."( (http:// www.amazon.com/A-Walk-to-Remember-ebook/product-reviews/B000SEI230/ref $=\mathrm{cm}$ cr pr top link 83?ie=UTF8\&showViewpo ints $=0$ \&pageNumber $=83$. (dod: January 12, 2012). This idea is also supported by marik ishtar111" who contributes his words on it, "my personal favorite part was right before the end when the two get married. I thought it was the most touching part of the book" (http://www. amazon.ca/productreviews/0446608955/ $\underline{\mathrm{ref}}=\mathrm{cm}$ cr pr top link 58? ie $=\mathrm{UTF} 8$ showViewpoints $=0 \&$ pageNumber $=58$. (dod: January 13, 2012). MizzImaginative also 
picks the same description of the most favorite part in the story, "I love the book and movie so much it always makes me cry I love the fact that they love each other so much and he marries her to make her happy even though he knows she's gonna die':(.’(http:// www.teenink.com/reviews/book_reviews/ article/64820/A-Walk-to-Remember-byNicholas-Sparks/. (dod: December 25, 2011).

From these explanations, it can be assumed that, such romantic dialogues we important in romance because it can arouse the readers' feeling. This idea seems to clarify that readers like to read romance novel which consists of several romantic parts such as beautiful sceneries and dialogues.

\section{- Ending}

Although "A Walk to Remember" is considered as a romance, this novel is different from other romances. According to readers' response from the internet sources, this novel is an interesting work since it is not merely talking about happiness, but it also contains sadness as this novel ends with the ending which arouses the readers' emotion. This idea is supported by a reader named FolkeB who states, "While reading this book not only you smile but you will end up crying" (http://www.librarything.com/work/8405130/ reviews. (dod: November 17, 2011). Since the story ends Jamie's death with, it touches the heart of the readers. Through this touching element, this novel has capacity for arousing the readers' sympathy. Chink6495 also supports the same idea with a different way in describing the sad feeling because of the lost of the female character, "This was my third time reading this book, and every time I read it, I get some sort of tears to my eyes. It is not only a love story, it is a story of how people can get through life and still love each other with the knowing of death" (http://www.librarything. com/work/8405130/reviews. (dod: November 17, 2011). For readers, what happened to
Jamie is assumed as tragedy that gets readers emotionally involved in the story. From previous several comments, it can be concluded that the ending of the story really moves reader's emotion. It can be seen that most readers cry a lot to express their feeling after reading the novel. This idea is supported by some readers who give their opinion on it. As A Customer states, "The ending of this book is one of the saddest I've ever read. Never having cried over a book before I was crying buckets and I just had to read it again" (http://A Walk to Remember Amazon.co.uk Nicholas Sparks 9780751538946 Books files/ site-wide-4187703703.js. V162394482. js. (dod: January 4, 2012). Other readers named Nandita(http://thebookhome.blogspot. com/2011/01/walk-to-remember.html. (dod: January 3, 2012) and Mehnaz (http://www. goodreads.com/topic/show/656310-who-elsecried-while-reading-this-book-especially-thelast-three-chapte. (dod: January 4, 2012) also have the same experience in reading the book. All readers agree that the ending is the saddest part of the story because it touches their heart feeling. It becomes interesting that readers pay big attention to the sad ending in this love story. Some readers also recommend this novel to be read because it arouses their sympathy. They recommend this book because it has capability for touching the heart of every reader. In other word, readers have imagination to feel the condition in the story. Egoose says, "I recommend Nicholas Sparks's $A$ Walk to Remember to all readers who are willing to let themselves cry and genuinely appreciate a one-of-a-kind love story" (http://www.librarything.com/work/8405130/reviews. (dod: November 17, 2011). Diana, Florissant also contributes her idea,

"This book was so good! A wonderful story of innocent love that is pure from the heart. Have plenty of tissue ready. It was hard to read the end because I was crying so much" (http://ebookstore.sony.com/eb- 
ook/nicholas-sparks/a-walk-to-remember/ /R-400000000000000095968. (dod: January 11, 2012).

From those several comments, it can be concluded that this novel is a romance which has the existence of the different ending in the romance. However, readers love this novel since it makes their feeling move, they can express what they feel by crying.

\section{- Gaining an Inspirational Way of Life}

- Knowing Jamie's Inner Quality

The book is successful in affecting the readers' emotion into the real life. There are lots of values that can be learned by the readers. One of readers named mamf agrees with this statement by saying, "A very heartwarming story. A great lesson to be learned from this story" (http://www.librarything.com/ work/8405130/reviews. (dod: November 17, 2011). According to readers, the interesting part from the novel is when Landon realizes that he makes a big mistake for being too cruel to Jamie just because of her appearance. The statement is supported by the following passage when Landon looks at Jamie's appearance. Landon thinks that Jamie is not a beautiful girl because she does not put make up on her face.

But Jamie wasn't exactly what I considered attractive, either. Despite the fact that she was thin, with honey blond hair and soft blue eyes, most of the time she looked sort of . . . plain, and that was when you noticed her at all. Jamie didn't care much about outward appearances, because she was always looking for things like "inner beauty," and I suppose that's part of the reason she looked the way she did. Even through our first three years of high school, she hadn't changed at all. The only thing that had changed was the size of her clothes (Spark, 13).

Readers pay more attention in this part by contributing opinion on it. Kirti S. posts her opinion, "this heart-wrenching plot touched me. I now really realize what people could do for love, and how a book, like Jamie and Landon, can't be judges by its cover" (http://www. amazon.ca/productreviews/0446608955/ ref $=\mathrm{cm}$ cr_pr top link 31?ie $=U T F 8 \&$ show Viewpoints $=0$ \&pageNumber $=31$. (dod: January 13, 2012). From the review, it can be seen that readers do not only enjoying the romantic and sad ending of the novel, but they also gain something worthy of life by giving appreciation for other people.

In the novel Landon also thinks that Jamie will never be one of his friend because there are lots of differences between them. One of the differences is that Jamie is not as popular as Landon. It makes Landon does not like to be around Jamie. Readers address their attention to the way Landon realize that Jamie is a great person for his life. Through this condition, readers see that there is a message of life that can be learned from the novel. The previous statement is clearly supported by A. Shen who states, "I liked this book a lot because the way it flowed. Everything was so detailed. The story has a moral; don't judge a book by its cover" (http://www.amazon.ca/ productreviews $/ 0446608955 / \mathrm{ref}=\mathrm{cm}$ cr pr top link 30?ie $=$ UTF $8 \&$ showViewpoints $=0$ \&pageNumber $=30$. (dod: January 13, 2012). The characteristic of Landon for being to be cruel to Jamie becomes the interesting part for readers. By seeing this phenomenon, it can be assumed that readers judge the cruelty of Landon as a bad action, but on the other hand, readers also take pity on Jamie. In addition, in accordance with the previous statement, another reader also contributes a similar opinion about the value from the story. From the following opinion, it can be seen that readers pay big attention to the message that is delivered by the novel. A Kid's Review states, "This book taught a very valuable lesson and it was that you should never judge a person by their appearance"(http://www.amazon.ca/productreviews $/ 0446608955 / \mathrm{ref}=\mathrm{cm}$ cr_pr top link 
27 ? $\mathrm{ie}=\mathrm{UTF} 8 \&$ showViewpoints $=0$ \&pageNu $\underline{\text { mber }=27}$. (dod: January 13, 2012).

Readers emphasize that this novel truly inspires their life. They learn so many good things from the story. The moral values for not giving judgment from someone else's appearance become an important thing in attracting reader's attention. It makes them enjoy reading the novel and recommend the novel to read. This idea is clearly expressed by Buzbee,

"My opinion on the book is that it has many great messages to send to readers. It makes me have a different perspective on life. Jamie makes you realize you shouldn't always judge someone on something by their looks" (http://www.barnesandnoble.com/ reviews/Walk-to-Remember\%2FNicholasSparks/1100307860?startat=161. (dod: January 16,2012 ). Since the value of life in the novel invites readers' attention, the novel influence readers' mind to better appreciate other people in real life. This fact makes readers adore the novel since it affects them in their real life as its moral value inspires them. This is supported by Hasini who contributes her opinion, "It may be the title of this novel that catches your eye, but this novel can change the way you look at a person after you read it. This novel teaches the readers very important lesson about life. It is that don't judge people by their appearance, but look for who they are inside" (.http://www.amazon.com/WalkRemember-Nicholas-Sparks/product-reviews 10446693804?pageNumber=2. (dod: January 4, 2012).

Finally, it can be concluded that readers have their own words in describing their favorite part in the novel. Although each person has different way in seeing the value, they agree that this novel is a good story which has good moral values of life. From all of the opinion which comes from readers, it is assumed that the moral value of the novel is important since readers need to have it in real life. The value of not judging person from the appear- ance becomes the one of the interesting parts for readers. Thus, it can be concluded that the novel succeeds in fulfilling the needs of the readers.

\section{- Through the Value In Changing Someone's Life}

The author of the novel truly understands how to make readers enjoy the novel. By creating such kind of story which contains some messages of life, the novel could bring the readers into a touching atmosphere. In addition, it also arouses the readers' spirit. This idea is delivered by Eric by stating, "There are parts in this novel that made me cry, and also it made me happy to see that these two people found love, and also it teaches how you can lose that love but still you change as a person inside and out" (http://www.amazon.ca/ product-reviews $/ 0446608955 / \mathrm{ref}=\mathrm{cm}$ cr $\_$pr top link 58?ie $=$ UTF8\&showViewpoints $=0$ \&pageNumber58. (dod: January 13, 2012). There is another similar comment stated by aharey, "One of my all-time favorite books, this is the story of Landon Carter and how his life was changed by Jamie Sullivan when he was seventeen"(http://www.librarything.com/ work/8405130/reviews. (dod: November 17, 2011). From the two readers' comments, it can be concluded that readers also put their big attention to the moral value of changing someone's life because it moves their emotion.

In the story, Jamie as the female character succeeds in changing Landon to be a good man. Von contributes her words in supporting the idea, "Jamie was really special and if you read the story you will know how she changes Landon's life forever"'(www.amazon. de/review/R1CVH2VUZVMITV. (dod: January 11, 2012). Jamie becomes an important person for Landon because she brings several good things into Landon's life. In the story Landon admits that Jamie helps him to be a great person. There are lots of changes in his 
personality since he knows Jamie. The book describes what Landon feels for Jamie. . It can be seen by the following passage that describes Landon's feeling:

Jamie was more than just the woman I loved. In that year Jamie helped me become the man I am today. With her steady hand she showed me how important it was to help others ; with her patience and kindness she showed me what life is really all about. Her cheerfulness and optimism, even in times of sickness, was the most amazing thing I have ever witnessed (Spark, 138).

The change of Landon's personality becomes an interesting part for readers. This idea is also expressed by Ekasatya's by saying, "After I read it, I'm really amazed by the power of love, love could change someone to be a good person" (http://blog.unsri.ac.id/ Yenny/writing/a-walk-to- remember/mrdetail/13410/. (dod: November 20, 2011). By seeing the readers' comments, it can be assumed that readers give attention to the power of love which succeeds in changing someone to be a better person. This part successfully moves the readers' feeling. Moreover, the book not only succeeds in inviting readers' emotion, but it also succeeds in influencing them in the real life. It means that most of readers recommend the book because of its value which is worth to be read. This idea is supported by Elvon J. White, "If you have ever loved someone read this book and learn how the love you have for that one person can change your entire outlook on life" (http://www.amazon.ca/productreviews $/ 0446608955 / \mathrm{ref}=\mathrm{cm}$ cr pr top link 76? $\mathrm{ie}=\mathrm{UTF} 8 \&$ showViewpoints $=0$ \&pageNu $\underline{\text { mber }=76}$. (dod: January 13, 2012). Further, Josette also says, "It's the kind of book where one may want to change to become a better person after reading it. And if you like books where the guy changes himself for the girl, then this is the book for you" (http://www. booksloveme.com/2007/11/a-walk-to-remember-by-nicholas-sparks/. (dod: December
$25,2011)$. Krissy also sees in the same way as she says, "The way Jamie had treated other and look at the world in a beautiful way had impressed me and motivated me to be a better person" (http://www.amazon.ca/productreviews $/ 0446608955 / \mathrm{ref}=\mathrm{cm}$ cr pr top link 28 ? ie $=$ UTF $8 \&$ show Viewpoints $=0 \&$ pageNu $\underline{\text { mber }=28}$. (dod: January 13, 2012).

As a result, it can be concluded that the readers expect these things such as the value in changing someone's personality to be included in the novel since it is important to be applied in life.

\section{CONCLUSION}

A Walk to Remember is a best selling novel which succeeds in attracting readers to read the novel. Since this novel is a story about a romantic relationship, it can be called a romance. There are several elements found in the novel that can be regarded as the formula of romance. From the elements found in the novel, it can be concluded that the romantic relationship in this novel attracts readers' attention since it is not merely a love story, but it is also a story which presents moral values. In addition, readers pay more attention to the ending of the novel which presents jamie's death. It can be said that the power of this novel to attract readers is not only achieved by creating the happy ending.

In addition, as the ending is successful in moving readers' emotion, it can be concluded that, $A$ Walk to Remember is considered more than a romance, it is considered as drama.

\section{BIBLIOGRAPHY}

Cawelti, John G. 1976. Adventure, Mysteryand Ro mance: Formula Stories as Art and Popular Culture. Chicago: The University of Chicago Press.

Iser, Wolfgang. 1980. "The ReadingProcess: A Phenom enological Approach" in Jane P. Tompkins, Read er-Response From Formalism to Post-Structural ism. Baltimore and London: The Johns Hopkins University Press. 
Nachbar, Jack and Kevin Lause. 1992. Popular Culture: An Introductory Text. Ohio: Bowling Green State University Popular Press.

Radway, Janice A. 1984. Reading the Romance: Women, Patriarchy, and Popular Literature. Chapel Hill and London: The University of North Carolina Press.

Sparks, Nicholas. 1999. A Walk to Remember. New York: Warner Books, Inc.

Stanton, Robert. 1965. An Introduction to Fiction.USA: Holt, Rinehart and Winston, Inc.

Ummul Hasanah. 2010. "The Popular Formula of New York times Best Seller Cathy's Book". Unpublished Graduating Paper, UGM. Yogyakarta.

Vanny Febrina. 2008. “Romance in JaneAusten's Pride and Prejudice: A Study on Literary Transforma tion". Unpublished Graduating Paper, UGM. Yogyakarta.

http://www.adherents.com/movies/WalktoRemember. html. (dod: June 15, 2011 at 7.33 am)

http:/www.amazon.ca/productreviews/0446608955/ ref $=\mathrm{cm}$ cr pr top link 27?ie $=U$ TTF $8 \&$ show Viewpoints $=0$ \&pageNumber $=27$. (dod: January $13,2012$ at $4.53 \mathrm{pm})$.

http://www.amazon.ca/product-reviews/0446608955/ $\underline{\text { ref }}=\mathrm{cm} \_\mathrm{cr} \_\mathrm{pr}$ top link $28 ? \mathrm{ie}=\mathrm{UTF} 8 \&$ show Viewpoints $=0 \&$ pageNumber $=28$. (dod: January $13,2012$ at $5.23 \mathrm{pm})$

http://www.amazon.ca/productreviews/0446608955/ ref $=\mathrm{cm}$ cr pr top link 30 ?ie $=$ UTF $8 \&$ show Viewpoints $=0$ \&pageNumber $=30$. (dod: January $13,2012$ at $5.25 \mathrm{pm})$

http://www.amazon.ca/productreviews/0446608955/

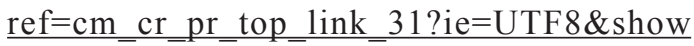
Viewpoints $=0$ \&pageNumber $=31$. (dod: January $13,2012$ at $5.25 \mathrm{pm})$

http://www.amazon.ca/product-reviews/0446608955/

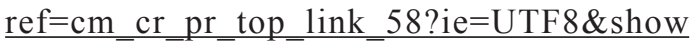
Viewpoints $=0$ \&pageNumber58. (dod: January $13,2012$ at $5.40 \mathrm{pm})$

http://www.amazon.ca/product-reviews/0446608955/ ref $=\mathrm{cm}$ cr pr top link $76 ? \mathrm{ie}=\mathrm{UTF} 8 \&$ show Viewpoints $=0$ \&pageNumber $=76$. (dod: January $13,2012$ at $5.54 \mathrm{pm})$
http://www.amazon.com/A-Walk-to-Remember-eb ook/product-reviews/B000SEI230/ref $=\mathrm{cm}$ cr pr top link 8? ie $=$ UTF 8\&showViewpoints $=0$ \& pageNumber $=8$. (dod: January 12, 2012 at $4.19 \mathrm{pm})$.

http://www.amazon.com/A-Walk-to-Remember-eb ook/product-reviews/B000SEI230/ref $=\mathrm{cm}$ cr pr top link 14?ie $=$ UTF8\&showViewpoints $=0$ \& pageNumber $=14$. (dod: January 12, 2012 at 4. $33 \mathrm{pm})$

http://www.amazon.com/A-Walk-to-Remember-eb ook/product-reviews/B000SEI230/ref $=\mathrm{cm} \_c r$ pr top link 17 ? ie $=$ UTF 8 \&showViewpoints $=0 \&$ pageNumber $=17$. (dod: January 12, 2012 at 4. $38 \mathrm{pm})$

http://www.amazon.com/A-Walk-to-Remember-eb ook/product-reviews/B000SEI230/ref $=\mathrm{cm}$ cr pr btm link 31?ie $=$ UTF8\&showViewpoints $=\overline{0}$ \&pageNumber=31. (dod: January 11, 2012 at 4. $56 \mathrm{pm})$

http://www.amazon.com/A-Walk-to-Remember-eb ook/product-reviews/B000SEI230/ref $=\mathrm{cm}$ cr pr top link 83?ie $=$ UTF8\&showViewpoints $=0$ \& pageNumber $=83$. (dod: January 12, 2012 at $8.49 \mathrm{pm})$

http://www.amazon.com/A-Walk-to-Rememberebook/product-reviews/B000SEI230/ref $=\mathrm{cm}$ _cr pr top ink 134? ie=UTF8\&showViewpoints= 0\&pageNumber=134. (dod: January 12, 2012 at $1.09 \mathrm{am})$

http://www.amazon.com/Walk-Remember-NicholasSparks/product-reviews/0446693804?pageNumb er=2. (dod: January 4, 2012 at 8.15 am).

http://www.amazon.com/Walk-Remember-NicholasSparks/product-reviews/0446693804/ref $=\mathrm{cm} \mathrm{cr}$ pr top link 6? $\mathrm{ie}=\mathrm{UTF} 8$ \& show Viewpoints $=0$ \& pageNumber $=6$. $($ dod: January 12,2012 at $4.16 \mathrm{pm})$

http://A Walk to Remember Amazon.co.uk Nicholas Sparks 9780751538946 Books files/site-wide4187703703.js. V162394482 .js. (dod: January 4, 2012 at $3.30 \mathrm{pm})$.

http://www.barnesandnoble.com/w/walk-to-remem ber-nicholas-sparks/1100307860. (dod: January $16,2012$ at $5.22 \mathrm{pm})$

http://www.barnesandnoble.com/reviews/Walk-to-Re member\%2FNicholas-Sparks/1100307860?s tartat $=141$. (dod: January 16, 2012 at $5.30 \mathrm{pm})$ 
http://www.barnesandnoble.com/reviews/Walk-to-Re member\%2FNicholas-Sparks/1100307860? startat $=161$. (dod: January 16, 2012 at 5.32 pm)

http:www//.bestseller-romantic-fiction-books.html. (dod: November 15, 2011 at $5.11 \mathrm{pm}$ ).

http://blog.unsri.ac.id/Yenny/writing/a-walk-to- remem ber/mrdetail/13410/. (dod: November 20, 2011 at $7.21 \mathrm{pm})$

http://www.booksloveme.com/2007/11/a-walk-to-re member-by-nicholas-sparks/. (dod: December 25, 2011 at $1.44 \mathrm{pm}$ )

http://www.dealtime.com/A Walk to Remem ber by_Nicholas_Sparks/a-walk-to-remember/ RD-70684216964/reviews. (dod: January 16,2012 at $11.14 \mathrm{am})$

http://www.dealtime.com/A Walk to Remember by Nicholas_Sparks/nicholas-sparks-ia-walk-to-re memberi-a-beautiful-book/RD-52407930500/ reviews. (dod: January 16, 2012 at 11.06 am)

http://ebookstore.sony.com/ebook/nicholas-sparks/ a-walk-to-remember/ /R-4000000000000000 95968.(dod: January 11, 2012 at 7.39 am) http://www.elizabethlowell.com/popfiction.html. (dod: November 15, 2011 at $5.05 \mathrm{pm}$ )

http://www.goodreads.com/book/show/3473.A Walk to Remember" $>$. (dod: November 15,2011 at 8.11 $\mathrm{pm})$.

http://www.goodreads.com/topic/show/656310-whoelse-cried-while-reading-this-book-especiallythe-last-three-chapte. (dod: January 4, 2012 at 8. $21 \mathrm{pm})$

http://www.librarything.com/work/8405130/reviews. (dod: November 17, 2011 at $12.30 \mathrm{pm}$ )

http://www.shellythacker.com/marketsavvy.htm. (dod: November 15, 2011 at $7.21 \mathrm{pm}$ ).

http://www.teenink.com/reviews/book reviews/ article/64820/A-Walk-to-Remember-by-Nicho las-Sparks/. (dod: December 25, 2011 at $3.21 \mathrm{pm}$ )

http://thebookhome.blogspot.com/2011/01/walk-toremember.html. (dod: January 3, 2012 at 9.38 $\mathrm{pm})$ 